\title{
Competitiveness of Gum Arabic Marketing System at Elobeid Crops Market, North Kordofan State, Sudan
}

\author{
Tarig E. Mahmoud ${ }^{1}$, Maruod E. Maruod ${ }^{2}$, Manal A. Khiery ${ }^{3}$, Ahmed M. El Naim ${ }^{3, *}$, Moayad B. Zaied ${ }^{3}$ \\ ${ }^{1}$ Department of Agricultural Economics and Rural Development, Faculty of Natural Resources and Environmental Studies, University \\ of Kordofan, Elobeid, Sudan \\ ${ }^{2}$ Department of Forestry Management, Faculty of Forestry, University of Khartoum, Sudan \\ ${ }^{3}$ Department of Crop Sciences, Faculty of Natural Resources and Environmental Studies, University of Kordofan, Elobeid, Sudan \\ *Corresponding author: naim17amn@yahoo.com
}

Received October 08, 2014; Revised October 13, 2014; Accepted October 15, 2014

\begin{abstract}
Gum Arabic (GA) subsector in Sudan is largely structured by performance of its marketing systems and prevailing policy intervention. The marketing systems of GA commodity are indicated by the rural traditional, the urban and the auction markets. The commodity has been exposed to different scenarios of policy innervations ranging from monopoly, concession, liberalization and oligopoly measures. The current paper is intended to describe and assess the competence of gum Arabic marketing system at Elobeid Crops Market (ECsM) under the prevailing policy measures. Investigations, in such respect, entail to identify of the active GA stakeholders, market infrastructures, administrative setups, marketing channels, forces of supply and demand, pricing mechanisms and quality control measures. The paper applied a composite of research methodologies including descriptive statistics and policy analysis matrix. The findings revealed that GA producers, as major stakeholders, do not often exist physically at ECsM. The gum Arabic companies do not show up directly at the auction market. Results emphasized varying comparative advantages and competiveness pertaining GA trade at the auction market. Additionally, the oligopoly nature of the market is still predominating despite the adopted liberalization measures. Having understood the nature and complexity of GA local marketing systems in the North Kordofan State, the current paper proposed some arguments for improving competence GA stakeholders in the market.
\end{abstract}

Keywords: Gum Arabic, sstakeholders, concession, oligopoly, liberalization

Cite This Article: Tarig E. Mahmoud, Maruod E. Maruod, Manal A. Khiery, Ahmed M. El Naim, and Moayad B. Zaied, "Competitiveness of Gum Arabic Marketing System at Elobeid Crops Market, North Kordofan State, Sudan.” World Journal of Agricultural Research, vol. 2, no. 5 (2014): 252-256. doi: 10.12691/wjar-2-5-9.

\section{Introduction}

Gum Arabic is an exudates [1] collected from the stems and branches (natural forest product) obtained from the various species of the genus Acacia [2,3]. However, only Acacia senegal (high quality gum) [8] and Acacia seyal (low quality gum) yield gum of economic significance $[3,4,5,6]$. The demand for gum Arabic is on the increase worldwide. GA is widely used as stabilizer, thickening agent and hydrocolloid emulsifier. It is mostly used in food industry and in other sectors such as textile, pottery, lithography; cosmetics and pharmaceutical industries [21]. The major determinant of the production of any industrial crop is its demand and the revenue derivable from it. That is, the better the market situation of a crop for higher production among farmers $[5,7]$. The majority of the populations in the gum Arabic producing areas in Sudan rely heavily on traditional agriculture, livestock and range activities due to their considerable contribution to the household food security [10]. GA commodity contributes significantly to the export portfolio of the country. Historically, Sudan commanded over $80 \%$ of the world's GA production and trade [9]. Enigmatically, Sudan's share of the GA world market has declined to about 50 percent as being lost to new producing countries in Africa [11]. According to records of the Gum Arabic Board [12], the GA export was around 30,000 tons in 2008 , increased $(57 \%)$ to 47,000 tons in 2009, increased again (17\%) to 55,000 tons in 2010, and then decreased (39\%) to 39000 tons in 2011. However, Sudanese farmers - who often produce gum Arabic in small groups with little efficiency - risk losing out to growing competition from other countries like Chad and Nigeria because fighting between rebels and the army in the farming regions of Sudan, Darfur, Blue Nile and south Kordofan, has hit production [13].

The GA marketing in Sudan before the inception of the Gum Arabic Company (GAC) apparently exhibited that auction markets were organized by the local government consuls as part of the crops marketing system. A minimum floor price was introduced to the auction system since 1922. The GAC has been established in 1969, and offered exclusive monopoly power on GA trade. Consequently, GAC was the sole exporter of crude GA from Sudan and the world price dominant supplier for 
about 40 years (1969-2009). The company was mandated to protect GA producers through sustaining a minimum (floor) price [14]. Moreover, it was authorized to supervise and promote the international marketing of GA with the objective of increasing its exports earnings and preserving the GA quality control [15]. However, recently in 2009, the GAC power was abolished and the newlyemerging GA processing companies have become very dynamic in GA marketing. From all these experiences, it is obvious that the marketing system of the commodity is directly structured the potential stakeholders involved at the different GA marketing levels. The system comprises the rural traditional, urban and auction markets [10]. The traditional GA marketing patterns, in turn, are aggravated by poor infrastructures, weak administration setups and policy distortions. These factors have severely affected GA marketing processes. Consequently, the producers and local traders in the rural markets receive very low prices or supplies much lower in values compared to their GA harvest [16]. The presence of these rural markets, as criticized by El-Tohami and Bateson [19] has a damaging effect of divorcing producers' response away from official pricing policies. Estimates of [11] showed that GA prices paid to producers in rural markets were for many years typically about 10 to 15 percent of the FOB prices. The on-going efforts exerted by some developmental projects like the "Revitalizing the Sudan Gum Arabic Production and Marketing” project financed by the World Bankadministered Multi-Donor Trust Fund- National, FNC and IFAD are trying to push up these percentages. the current study proposed some arguments for improving competence GA stakeholders in the market and to assess the role of gum arabic stakeholders at Elobeid Crops Market under different policy measures. Specifically, this entails to display of the role of stakeholders pertinent to market infrastructures, administrative setups, marketing channels, forces of supply and demand, pricing mechanisms and quality control measures.

\section{Materials and Methods}

\subsection{Selection of El Obeid Crops Market}

Elobeid crops market (main central), was selected on the basis of some economic and non-economic arguments. In this context, the market supplies more than $50 \%$ of GA commodity in the country in addition to the availability of marketing records since 1950s. This is besides prevalence of large and diversified number of GA stakeholders.

\subsection{Data Collection}

Participatory learning and action (PLA) and other relevant approaches were pursued to assure good coverage of stakeholders' participation. Interviewing questionnaires with GA stakeholders were conducted. Meetings with different stakeholders and related groups (viz. gum Arabic production associations, businessmen federations, custom and tax authorities, quality control units ... etc.) were undertaken. Personal observations were documented with the aid of digital devices. Secondary data were extracted from the market reports and previous studies. Time series data for quantities and prices of GA commodity were obtained from different sources.

\subsection{Analytical Tools}

The collected data were analysed using descriptive statistical measures and Policy Analysis Matrix (PAM). PAM as an empirical framework was used to display the degree of government interventions and market failures effect on comparative advantages and competitiveness on the auction market. This exhibits itself in terms of some PAM coefficients like DRC (domestic resource cost ratio), CIC (coefficient of international competitiveness) and EPC (effective protection coefficient). These coefficients were calculated on the basis of Monke and Pearson [17] and Pearson and Gotsch [18].

Whereas:

The EPC is defined as the ratio of value added in market prices to value added in world prices.

The DRC, as a measure of efficiency or comparative advantage, is calculated by dividing the costs of marketing (in economic prices) by the value added evolves from the marketing process (in economic prices).

The CIC is defined as the ratio of the domestic resource costs measured in economic prices and expressed in domestic currency (SDG), to the international value added (IVA) expressed in foreign currency (US\$).

\section{Results and Discussion}

\subsection{Infrastructures}

Elobeid crops market, initiated in 1905, consists of different specialized units; information office, auction hall, market yard, executive authority office, electronic balance (maximum load 70 ton $\pm 20 \mathrm{~kg}$ ), 20 conventional balances, and nursery. Other offices are allotted for representatives of alms (Zakat), taxes and duties, quality control, merchants, producers' agents and companies' agents. Basic services of water and electric power are available in addition to security elements. There are no storage facilities in the market. Management manpower in the market is more than 100 people, in addition to other employees (taxes, quality control, FNC and alms). Despite deficiency in some essential assets and poor market information system, Elobeid crop market is comparatively the most appropriate GA auction market in the country.

\subsection{Marketing Channels}

Gum arabic marketing channels refer to the vessels whereby gum arabic commodity is transferred from producers to the central markets as El Obeid and Ennuhud Crops Market. GA marketing channels differ a little in each market level due to the variability in number and types of stakeholders, distance to the central market, accessibility all over the year and means of transportation.

\subsection{Stakeholders}

Three types of stakeholders dominate Elobeid crops market. These are the producers' agents, city merchants and companies' agents. This is beside the executive authority related to market daily work. GA producers do not physically exist at the auction market due to some reasons argued by the key informants. These arguments imply that producers do not satisfy auction market requirements, they are scattered over remote areas from 
the auction market, a considerable portion of them are not aware of auction markets, some of them preferentially sell their GA product at low prices to meet their urgent daily needs and the quantity required by auction markets is relatively beyond their capacity.

With regard to the number of traders during the GAC concession, Figure 1 expresses the number of registered traders in Elobeid auction market for the period (20052009). The trend of their number showed significant $\left(\mathrm{R}^{2}=\right.$ 0.677) decline for the prescribed period. This is presumably ascribed to disfavoring gum Arabic prices offered at the auction market, lack of credit facilities, high taxes and fees and fluctuation in gum Arabic production.

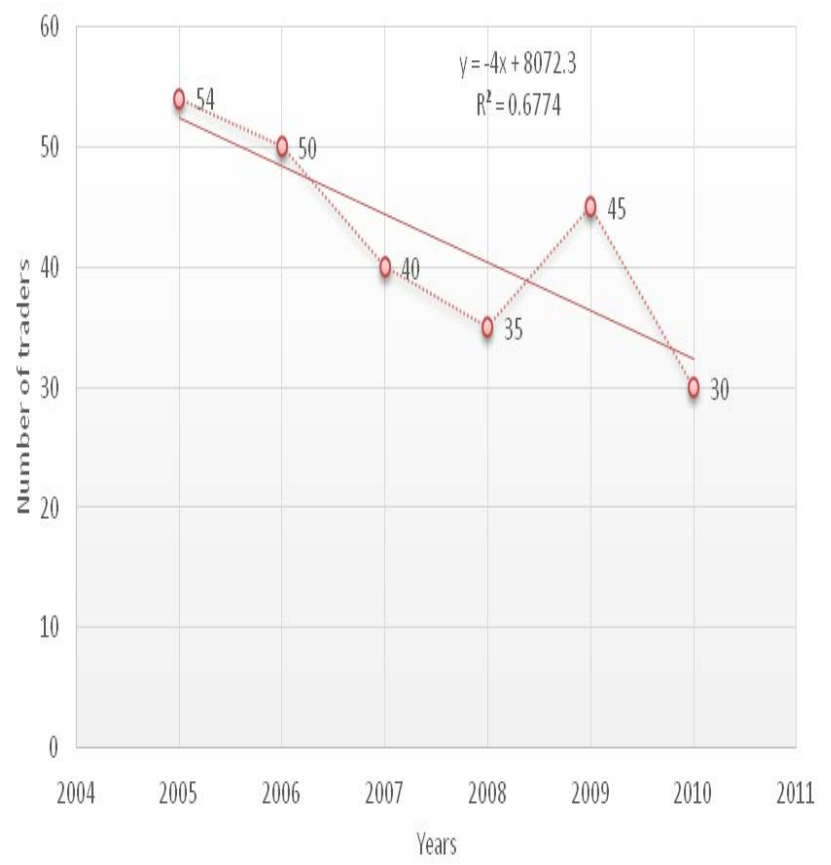

O- Number of traders — Linear (Number of traders)

Figure 1. Number of registered traders at Elobeid crops market during 2005-2010 Source: ECsM [20]

The findings also illustrated that despite their crucial role in the GA auction markets, gum Arabic companies do not show directly at the auction market. The reasons behind are primarily the severe taxes and crops alms (Zakat Elzroa). Furthermore, there is a general consensus among gum Arabic companies that their physical appearance at the auction market will lead to a substantial jump in GA prices. Nonetheless, some companies have active agents at the rural and urban GA markets. It is worth to note that auction competition for GA is presently decreased presumably due to the relatively few dealers which could be described from economic standpoint as sheer oligopoly. This phenomenon implies that dealers in the gum Arabic auction market do not exert efforts towards favoring neither small producers nor rural traders as mandated by GAC.

Gum Arabic companies don't show up physically in the auction market and concurrently perform their active transactions in rural and urban markets. This could be attributed to inadequacy in price incentives provided by the auction market and high taxes versus preferential profit margins offered in rural and urban markets.

\subsection{Market Forces and Pricing Mechanisms}

Based on the current price liberalization policies issued by the Presidential Decree in 2009, the GA minimum floor price is no longer valid. This situation, most likely, leads to uncertainty of GA prices, especially in rural and urban markets. Though the interviewees at Elobeid crops market assured the competitiveness of gum auction market, the cross-checked investigations revealed that GA price is solely determined by the buyers (traders, middlemen and companies' agents). The observations gathered by authors also emphasized that the sellers of the commodity at the auction market deliberately keep low profile, in most cases, during the bidding process. In this context, the interviewed stakeholders (80\%) alleged that the market is of a competitive nature (Figure 2). However, the analysis refuted this idea in the sense that the market is an oligopoly rather than competitive one. Again, the few numbers of registered gum Arabic traders and companies confer strong arguments in favoring the oligopoly nature of the auction market.

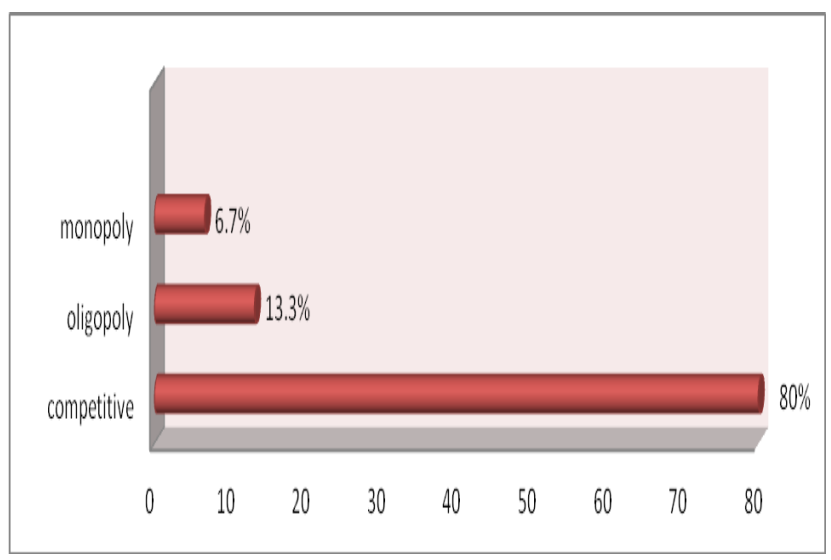

Figure 2. Nature of Elobeid crops market according to the interviewees

\subsection{Quantities and Prices of Gum Arabic}

The quantities of gum Arabic received at Elobeid crops market during 1960-2009 showed fluctuations with a trend of a steady decline (Figure 3).

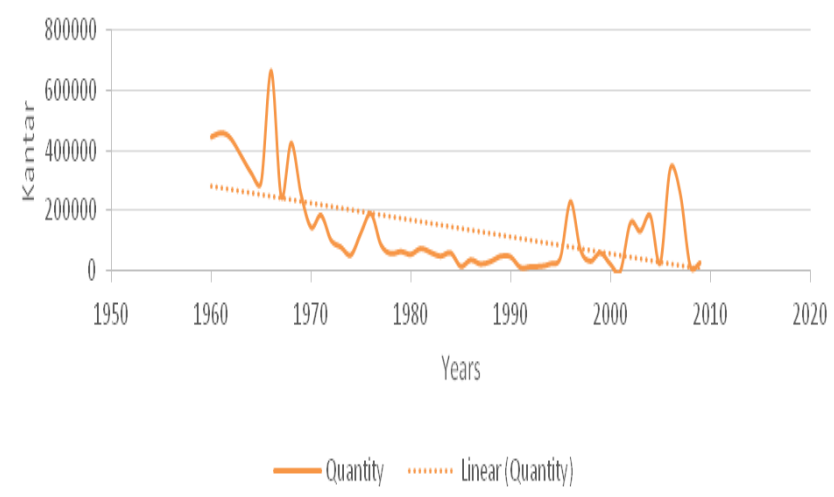

Figure 3. Quantities of GA received at Elobeid Crops Market (19602009) Source: ECsM [20]

One of the most expressive findings is that the combined quantities that reported at the market during the ten years period (1960-1970) were surprisingly much higher than those received during the subsequent 38 years (1971-2009) collectively. The deterioration in gum Arabic quantities received at Elobeid crops market during the last 
38 years might be attributed to the disincentives created by policy distortions and market imperfections. It is conceivable that total GA supplies to be received at auction markets will be decreasing during this season (2011) and subsequent seasons due to the serious problem of the deviation of the labor force from gum and crops production to conventional gold mining in all states where gold has been discovered, especially North Kordofan State.

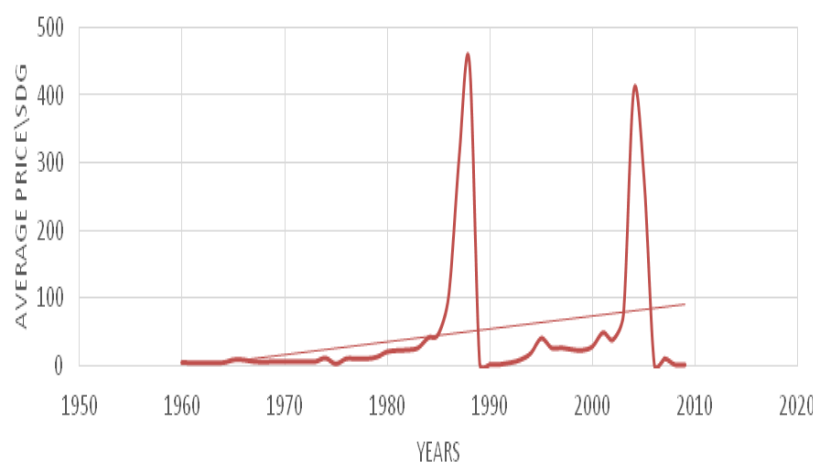

Figure 4. Average prices of GA per kantar received at Elobeid crops market Source: ECsM (2010)

It worth to note that during season 2005 (Figure 4), the price of GA per kantar tremendously escalated due to most likely market speculation. It seems plausible that higher prices in 2005 led to more quantities in the next season 2006 and 2007. However, the negative impacts of these higher prices (not followed by the international prices of gum Arabic) have led to accumulation of huge gum Arabic quantities in the hands of companies, big names in the business and financial institutions (banks). It was difficult for the authors to report the quantities supplied and purchased at markets like Abugebaiha and Umgafala. This is mainly due to the absence of market records. Despite that, some appreciable quantities were traded and stored in these markets as expressed by interviewees.

\subsection{Comparative Advantage and Competitiveness of Gum Arabic in Elobeid Auction Market}

The PAM was applied to investigate the effect of price policy interventions on gum arabic commodity in Elobeid auction market. This was done through testing the adequacy of price incentives generated from financial returns per kantar of GA for the years 2007, 2008 and 2009.

As presented in Table 1, the following empirical indicators were obtained and explained as follows:

The effective protection coefficient $(\mathrm{EPC}<1.0$, and decreasing from 2007 to 2009) emphasizes the cumbersome burden of direct and indirect taxes imposed on marketing of GA commodity. As a result, the prevailing price policies were considered discouraging the competitiveness of the commodity in the auction markets i.e., the incentives offered through the auction prices were not satisfactory promoting gum Arabic stakeholders. The results also justify that the gum Arabic auction prices were not determined on the light of the export prices.

The domestic resource cost ratio (DRC $<1.0$, and increasing from 2007 to 2009) for GA auction market indicates a positive (but decreasing as from 2007 to 2009) comparative advantage of the commodity in the auction market.

The coefficient of international competitiveness (CIC) shows that the GA commodity obtained from the auction market is internationally competitive despite the distortion created by government interventions and market inefficiencies.

Though the rural and urban markets of GA (e.g. Umgafala and Abugebaiha markets) were not investigated by PAM analysis due to deficiency of some technical data, the PAM model is expected to exhibit different indicators.

Table 1. PAM indicators for GA commodity in Elobeid crops markets

\begin{tabular}{|c|c|c|c|}
\hline Year & EPC & DRC & CIC (SDG) \\
\hline 2009 & 0.41 & 0.53 & 177.39 \\
\hline 2008 & 0.77 & 0.36 & 135.00 \\
\hline 2007 & 0.83 & 0.29 & 101.55 \\
\hline
\end{tabular}

\section{Conclusions}

Based on the results obtained the oligopoly nature of the market is still predominating despite the adopted liberalization measures of Gum Arabic Marketing at Elobeid Crops Market, North Kordofan State, Sudan. The following measures are suggested for future prospects of Gum Arabic Marketing.

Encouragement of intellectual (smart) partnerships between GA producers and the private sector on the basis of benefit sharing or powerful sharing to assure the presence of GA producers in all levels of markets.

Facilitation of microfinance through easy collaterals for GA producers and local traders.

Changing official perception on GA markets from being markets for levying revenues to markets for providing real services.

Auction markets should be pushed towards more realistic and competitive transactions in a sense that prices of gum Arabic to be determined on the light of market forces (supply and demand).

Improvement of infrastructures at the gum Arabic markets.

Activation of quality control and standard units at these markets.

Implementation of gum Arabic insurance services in all markets.

Provision of marketing information systems via establishment of well-equipped trade points and initiation of scientific database for gum Arabic trade.

Establishment of powerful networking to connect rural, urban and auction GA markets.

\section{References}

[1] Almuslet, N. A. Elfatih A. H., Al Sayed, A.A., Mohamed, G. M., "Diode Laser (532 nm) Induced Grafting of Polyacrylamide onto Gum Arabic,”. Journal of Physical Science, Vol. 23 (2), 43-53, 2012.

[2] Sagay, G. A. and Mesike, C. S., "Socio-economic Factors Associated with Gum Arabic Production in Nigeria,” J Soc Sci, 26 (1): 41-45, 2011

[3] Rahim, A. H. Ekko, C. I. and Weikard, H., "Competition in the gum arabic market: a game theoretic modelling approach,”. Quarterly Journal of International Agriculture, 49 (1): 1-24, 2010. 
[4] Odo PE, Oleghe PE 1998. The production and management of gum arabic (Acacia senegal) wild in the Sudan and Sahelian zone of Borno state. Journal of Arid Agriculture, 1 (2): 157-266.

[5] Wuranti, V, Giroh, D.Y., "Economic Analyses of Gum Arabic Production in Yobe State”. Nigeria. Journal of Tropical Agriculture, 7 (1): 56-61, 2005.

[6] Yassen, G. A. M., Salih, A. A., Ahmed, M. E. D. "Competitiveness and profitability of Gum Arabic in north Kordofan state, Sudan,”. Procedia-Social and Behavioral Sciences, 120 (2014) 704-710, 2014

[7] Oleghe, P. E., "Production and Management of gum arabic in Sudan and Sahelian zone of Nigeria”. Journal of Agriculture, 20: 257-266, 1998.

[8] Qi, W., Fong, C. \& Lamport, D. T. A., "Gum Arabic glycoprotein is a twisted hairy rope,” Plant Physiol. 96, 848-855, 1991.

[9] Taha M. E., Tsegaye, B. Elgaleem, A., "The role of the cooperative societies of Gum Arabic Producers in promoting gum Arabic production and marketing in North Kordofan State, Sudan,”. International Journal of Agriculture, Forestry and Fisheries, 1 (1):11-16, 2013.

[10] Mahmoud, T. E., The Adequacy of Price Incentives on Gum Arabic Production and Marketing: A Case Study of North and West Kordofan. PhD Dissertation, Institute of Forest Economics \& Management Planning, Dresden University of Technology, TUD Press, Germany, 2004.

[11] Couteaudier, T.Y., Export Marketing of Sudanese Gum Arabic, Multi Donor Trust Fund-National, World Bank, Khartoum, 2007.

[12] Gum Arabic Board, Official records of Gum Arabic Board, obtained from custom tariff Office, Khartoum-Sudan, 2012.

[13] FPA, Food Processing Africa. A digital magazine focusing on business-assisting food applicable technologies and opportunities for small, medium and large enterprises in Africa. PS Publisher, 2013.

[14] Taha, M. N., The Socio-Economic Role of Acacia senegal in Sustainable Development of Rural Areas in the Gum Belt of the Sudan. PhD Dissertation, Institute of International Forestry and Forest Products (Tharandt), Technical University of Dresden, Germany, 2000.

[15] Karama, M., “Gum Arabic Marketing Issues: Marketing Model, Buffer-Stocking, Processing and Finance'”. Unpublished Paper Presented by the International Workshop on Promotion of Gum Arabic Production, Processing and Marketing (2002). Khartoum, Sudan.

[16] IIES \& IES, Gum Arabic Rehabilitation in the Republic of the Sudan. Stage 1 Report. Volume 2. Main Report and Recommendations for Action. International Institute for Environment and Development, London, England and Institute of Environmental Studies, University of Khartoum, Sudan, 1990.

[17] Monke, E. A. \& Pearson, S. R., The Policy Analysis Matrix for Agricultural Development. Cornell University Press, Ithaca, 1989.

[18] Pearson, S. \& Gotsch, C., The Policy Analysis Matrix. Workbook Version, 2002.

[19] El Tohami, A. \& Bateson, W. M., Sudanese Gum Arabic Production: Supply Function Estimates and Policy Implications. A Paper Submitted to Planning and Agricultural Economics Administration, Ministry of agriculture and Natural Resources Khartoum (Sudan). Washington; D.C., 1986.

[20] ECsM, Elobeid Crops Market. Annual Archive of Gum Arabic Commodity, Information System Unit. Elobeid. North Kordofan, Sudan, 2010.

[21] Ali, B. H., Ziada, A. \& Blunden, G., "Biological effects of gum Arabic," A review of some recent research. Food Chem. Toxicol., 47, 18-23, 2009. 